\title{
Alumni Networks
}

\section{-An Untapped Potential to Gain and Retain Highly-Skilled Workers?}

\author{
Alexandra David ${ }^{1} \&$ Frans Coenen ${ }^{2}$ \\ ${ }^{1}$ Institute for Work and Technology, Westfälische Hochschule, Gelsenkirchen, Germany \\ ${ }^{2}$ University of Twente, CSTM, Enschede, The Netherlands \\ Correspondence: Alexandra David, Institute for Work and Technology, Westfälische Hochschule, Gelsenkirchen, \\ Germany. E-mail: david@iat.eu
}

Received: July 22, 2014

Accepted: August 27, $2014 \quad$ Online Published: September 20, 2014

doi:10.5539/hes.v4n5p1

URL: http://dx.doi.org/10.5539/hes.v4n5p1

\begin{abstract}
In times of increasing skills shortage, regions and particularly non-core regions, need to attract highly-skilled workers. It is better for these regions to (re)-attract highly-skilled workers that gained knowledge and contacts elsewhere and because they once lived in the region for study have already ties to the university region than trying to attract outsiders without such ties. In general, social networks can contribute to nurturing a "warm place" perception among potential workers. This paper looks at special kinds of social networks. It focuses on higher education alumni networks and discusses their role in retention and (re)-attraction for increasing the highly skilled workforce in their university regions. Being part of a university community means that alumni networks are able to maintain continuous contact with their alumni and have a positive effect on students remaining in the region. This can occur through co-operation with the regional economy. However, the current study found that the analysed alumni networks were set up primarily as communication instruments for graduates and alumni and not for regional economy purposes. If elements of retention and (re)-attraction are found in the network activities, this is more an unintentional side effect than a purposeful attempt to contribute to the regional economy. This paper argues that alumni networks could take on such a retention and (re)-attraction function if they broadened their scope of activities and reorganized their management structure. Alumni networks are an untapped potential, which can be activated for regional purposes.
\end{abstract}

Keywords: alumni networks, brain circulation, highly-skilled workers, human capital, knowledge transfer, retention and (re)-attraction, social networks

\section{Introduction}

This paper is an explorative descriptive study into the goals, structure and function of so-called alumni networks. Alumni, as regarded in that paper, are graduates of higher educational institutions. But also former employees and associates of universities or similar educational institutions can be considered as alumni (Rohlmann \& Wömpener, 2009; alumni-clubs.net). The term alumnus is known from Latin. The exact translation of alumnus means fellow, companion or pupil. At one time it was used in the context of church education institutes (Niebergall, 2007). History shows that alumni networks are about 200 years old and were fixed at the first graduates' meeting in Yale. Primary American universities formed the term alumni in the sense of how it is used today (Rohlmann \& Wömpener 2009). There still is a lack of empirical research into the goals, structure and function of alumni networks in the northwest European context (Rohlmann \& Wömpener 2009). This paper wants to explore a particular potential function of alumni networks, namely the role alumni networks can play in brain circulation and return migration. Under brain flow this paper defines a natural phenomenon of highly-skilled human capital moving from one country or region to another. Brain circulation describes the highly-skilled workers migration and subsequently (re)-migration processes between two or even more regions including passing national borders. It is a brain flow from one country or region to another, where the brains return after a certain amount of time. In contrast to knowledge transfer, brain circulation describes the de facto movement of persons between several regions. Knowledge transfer concerns the transfer of knowledge in possession of highly-skilled workers from one region to another through migration processes. This paper defines the term region in the sense of NUTS2 (statistic regions). Research shows that people who once lived in a 
specific region for instance to study, will have (stronger) ties to their place of birth or place of study, and are more willing to move back to their study or birth region for a job, than people who are completely unfamiliar with a region (Smeulders \& Latten, 2009). As Hospers (2010, p. 188) formulates “(...) keeping existing customers is more profitable than acquiring new ones". These ties to a region are not only built on the personal experiences of living there but also on established networks and interconnection with people in this region. In that context a special meaning is assigned to migration networks (Andrews, 2012; Lowe et al., 2012; Pries, 2001a). These are, to a great extent, responsible for migrants' choice of staying, leaving or returning to a region.

This paper discusses that such a return mechanism not only depends on "warm place" feelings (positive experiences connected to a specific region) but also on social networks that cultivate the ties with the region. And that "warm place" feelings and "warm ties" in itself are normally not a sufficient reason to return to a region, but that there also needs to be an established communication about opportunities in the region for returnees and networks, which support the decision of a return.

Given the argumentation above, this paper asks the following questions:

1) What is the relation between brain flows and alumni?

2) Under what conditions can alumni networks supply to the retention and (re)-attraction of alumni in a particular region?

3) What is the present form and function of the studied alumni networks in northwest Europe and do they fulfil the formulated conditions?

\subsection{Brain Flows and Alumni}

\subsubsection{Alumni as Carries of Knowledge}

University alumni are a potential source of high educated staying or coming to a region. Regions and their economies strongly depend on skilled employees because they are recognized as the carriers of knowledge (Trippl \& Maier, 2007). "In innovation systems competence and human capital as a whole are important resources." (Seppänen, 2008, p. 10). A strong pool of human capital is the main competitive factor for each region (Growe, 2009; Heßler, 2008). Highly-skilled workers dispose of unique knowledge which foremost is required in high technology and knowledge-based sectors. Therefore, the success of regional economies depends on the quantity, but even more strongly, on the quality of human capital, which is mainly available in the form of talented and aspiring workers (Champion, 2012; Florida, 2008). Talent contributes to regional performance in the form of: (1) knowledge generation, (2) knowledge exploitation and (3) knowledge exchange. In addition, the continuous inflow of external knowledge is an essential precondition for regions' competitiveness (Martin \& Sunley, 2006; Malmberg \& Power, 2005; Butzin, 2000). Labour migration is the main source for absorbing external knowledge (Faggian \& McCann, 2008). Following these lines, Brain Flow is a normal occurrence, which describes the mobility of highly-skilled workers. Through moving across regions, the highly-skilled may contribute to regional innovation systems and can be even seen as innovators (Pries, 2011). Thus, the importance of highly-skilled workers to regional economic and social growth cannot be denied (Danzer \& Ulku, 2011; Saxenian, 2006; Cessarino, 2004; King, 1978).

\subsubsection{Alumni as Re-Migrants}

Regions profit from migrants or mobile people coming to a region and sharing their external knowledge (Klagge \& Klein-Hitpaß, 2010; Saxenian, 2006). An outflow of graduates can be regarded as a positive phenomenon if they acquire competences, experiences and contacts elsewhere and actual return at some moment in their life to their domestic or study region and make there a contribution. Brain drain in terms of people leaving a region is not a problem in itself (Coenen \& Fikkers, 2010). But if a region lists a higher outflow of skilled people and a lower inflow from elsewhere regions run the risk of imbalance, if a shortage of skilled people is created. In such a case, the region loses competencies (Stark \& Byra, 2012; Stark, 2005), which can lead to social and economic disadvantages. Regions with high brain drain levels report loss of knowledge, a reduction in purchasing power and the absence of cultural activities (Wagner et al., 2013; Malecki, 2011). Surveys have shown (Stockhorst, 2011) that brain drain particularly affects less attractive non-core regions such as border and/or peripheral regions. This paper understands non-core regions as regions that are not considered to be one of the more important economic regions in their country. The case regions analysed for this publication were also border regions, being relatively close to a neighbouring country.

For these non-core regions finding a balance between outmigration and immigration might be a problem and the attraction of highly-skilled workers is a challenge due to their specific regional socio-economic and geographical characteristics. Highly-skilled workers may assume that desirable jobs are found mostly in metropolitan areas 
(Florida, 2008), all of which are seen as attractive. But actually knowing a region because one lived there might change the ideas about job opportunities and quality of life, so for non-core regions return migrants are even more important. This paper supposes that return migrants as mentioned before have "warm feelings" or personal ties to the region of origin. Following this argument, alumni networks regarded as social networks own the potential to cultivate these personal ties and to create a warm feeling about the region itself and in that sense (re)-attract the alumni. Focusing on university alumni as (re)-migrants meet the two above-mentioned conditions as graduates of a specific regional university they are (1) considered to be among the highly-skilled workers, and (2) at its best they are bond emotionally to the region itself. The latter aspect should be differentiated in the way, that the emotional bond and even loyalty can only be seen as a supportive advantage for (re)-migration, if the emotions are positive in the sense of a "warm feeling". Universities can support the building of such a feeling, by establishing social networks such as alumni networks and by acting as a pipeline transforming global trends to local demands.

\subsection{Universities as Global/Local Pipelines}

Since finally Etzkowitz \& Leydesdorff (2000) expended the understanding of the university within an innovation system, at the same time they explained the important role of universities in the regional context. The authors did it by describing the path shift from "mode 1", which was the traditional concept of knowledge generation by means of a hierarchically, disciplinary and homogeneous approach (Gibbons, 1994), moving to the path of "mode 2", which in addition to a knowledge generation, is also knowledge production and even distribution. This new understanding of the role of a university could also be called in a broader sense the "commercial" role of a university. In that sense, university was no longer regarded only as a knowledge incubator, generating knowledge exclusively for the academic world, but rather as a stakeholder and a contributor to regional economy by e.g. university spin-offs. In that open up process to the outside world, universities are viewed as involved in deeper anchoring processes into global networks. By considering regions as places where global resources flow by using several channels of exchange (Appadurai, 2008 uses the term "scapes"), which can be embedded into local regional innovation systems (Cook, 2001), each drawing on their own global networks (Benneworth \& Hospers, 2007), universities offer regions access points to global networks and on the other hand transform the external flows/trends to answer local demands. Since being considered as a node in a network (Granovetter, 1973), universities can act as global and local pipelines (Bathel et al., 2004). Following these lines, universities are attributed to the tasks to interact with several actors in the outside world, among them also non-university stakeholders - such as private companies or public administration - and thereby they contribute with their knowledge and global academic and commercial links to the regional development, which is called in literature the universities "third mission" (Kroll et. al., 2013).

\subsection{Building Social Networks for Regions}

There are several studies, which point out the importance of networks for regional economies. All these networks, if these are company's networks such as clusters (Porter, 1998; Rehfeld, 1994) or governance networks (Bressers $\&$ O' Toole, 1998) or the so called innovation networks such as the Triple Helix, the co-operation between universities, industry and government (Etzkowitz \& Leydesdorff, 2000), or even the Quadruple and Quintuple Helix, expended by civil society and media and culture-based public (Carayannis et al., 2012) have one element in common. They are in broader sense social networks. Social networks are characterized by the interaction, exchange and even co-operation between the participated members (Boshuizen, 2009). Thus, they are not black boxes, but in best cases fluent "give-and-take" platforms. Alumni networks can be considered as social networks and a component of regional based universities. Therefore, they are the live string of contact between former university students who had lived in, or were even born in the region. Generally, alumni networks make contact with university students before they graduate and continue the contact when the students later become the universities' alumni.

The main characteristic of networks is the interdependency between actors and the exchange of resources. Different kinds of networks are based on different resources. Alumni networks are social networks and constitute to social capital (David \& Hamburg, 2013; Fürst \& Schubert, 1998), if they provide their members with knowledge and information, which is an added value for their members, and at the same time, the members' exchange among each other creates an added value for the regions by knowledge generation and exchanged and information transfer (David \& Hamburg, 2013). The idea of a social network suggests the importance of emotional engagement for a specific network and not just relation based on service for money. If an alumni network as representative of the university, once part of (alma mater), is only providing services for money without this emotional engagement and without members exchanging among themselves, there is only a seller-buyer relationship. Social networks are driven by the members of their community (in both directions) and 
therefore contain social capital. They thrive on relationships and are built on the fact that members share commonalities. Social networks are motivated by emotions, but also by expected benefits. The described emotions can be influenced during the time of their study. Literally spoken if a warm and positive feeling about the network is transferred and a kind of return investment is given, alumni relations can flourish through binding students to the university and even the region. Hence, the success of social networks, and in this special case of alumni networks, depends on the input level of individual members and the social capital as added value for each single network member (Boshuizen, 2009; Castells, 2008; Granovetter, 1973). Members' commitment depends on (1) the benefit members expect from the network participation and (2) the level of the connectivity to the network. According to both determinants, members of alumni networks weigh up what they can bring and what they can get in return or what they have already received. When deciding whether to join a network, alumni consider the services they will receive from the university and if they will improve their career opportunities. Therefore, the level of commitment of the alumni depends to a large extent on how they rate the quality of their higher education, their assessment of how well they were prepared for their career and what positive influences were exerted by individuals at the faculty (Weerts et al., 2009). So potentially alumni networks as social networks can contribute to (1) creating a warm feeling which binds students emotionally to the alma mater and university region and by (2) informing the later alumni (wherever in the world they are) about the latest university developments as well as economic developments in the domestic regions or former study regions.

\subsubsection{The Function of Alumni Networks for Universities}

\subsubsection{The Friend- and Fundraising Function}

Alumni networks are an old idea. In the 1920s (Niebergall, 2007) alumni organisations were originated in America at the private higher education institutes. Following, public universities used alumni mainly in terms of financial manners. There is a strong commitment of American students and alumni for their alma mater. This can be put down to a different education system as Niebergall (2007) presents. Public higher universities employed the concept of alumni according to the motto: building a relationship to students not only for the years of study but rather for a lifetime brings lifelong benefits to both - the university and the alumni. Professional alumni networks and alumni relations remain part of each American private and public higher education institution. To understand the commitment of American students and alumni for their alma mater means to look behind the scenes of American donating, associating and higher education culture. This extremely differs from the European higher education culture. In contrast to numerous European higher education systems, the American system is intensely supported by funding instruments and students' fees. These funding instruments rely on students' and graduates' "friend-raising", fundraising and sponsoring activities. American universities understand their calling in a different perspective to most of those in Europe.

They regard themselves not only as higher education institutions - even if the quality of study is one of the main factors for alumni to be proud of their alma mater - but as service providers. Enrolling to study involves obtaining a wide range of educational, cultural and social activities (Stifterverband, 2000). Therefore going to a university means going for a certain future way of life that will be designed by the educational image and activities provided by the university. Moreover, the choice of university is heavily influence by its alumni. Who the alumni are or have become and whether their private and working lives are proceeding in a positive way, impacts on visions of the future held by university students who want to follow a similar route and who share the same alma mater. American universities wish their students and alumni to take an active part in their universities' strategic and daily business both during and after their studies. Alumni adhere to the concept of giving something back to their alma mater, in the sense of investment return. They are part of the university advisory board before and after graduation. They give lectures, provide job opportunities for students and graduates, establish their careers, act as ambassadors or prominent university alumni through advertisement, acquire new students, act as mentors and give financial support to the university (Weerts et al., 2010).

\subsubsection{Alumni Networks as Competitive Factors in the Global Education Market}

At European universities, the importance of alumni and alumni networks began in the 1980s and was mainly driven by international and global pressure on universities to stay competitive and attractive. (Rohlmann \& Wömpener, 2009; Niebergall, 2007). Later in the 1990s, alumni became an active part of universities as their roles changed from knowledge generators and producers to knowledge providers. These effects were later enhanced by new media including E-Learning, faster communication and increased student mobility within the European Union (EU). Over time, the role of alumni and alumni networks seems to have been under constant change. Up until 2000 there were only a few publications on the broader topic of alumni in Europe (see Stifterverband 2000). Later there were several publications, which looked at the role of alumni networks in the 
context of overall university strategies and the alumni role being used as a financing instrument. (McDearmon, 2011; Rohlmann \& Wömpener, 2009; Weerts et al. 2009; Sung \& Yang, 2008; Niebergall, 2007). Set against this background, it would seem that alumni networks are an innovative idea for new European university structures. In the last few years, alumni networks have attracted more interest in public discussion brought about by the switch of several European higher education systems. Under the pressure to stay attractive and competitive, already in the 1980s first university changes appeared creating a new university profile. The new profile was an opening up process of European universities running parallel with a decline of public funds in some EU states. At the time alumni networks were identified as a competitive factor and further financial source.

\subsubsection{The Function of Alumni Networks for Regions}

\subsubsection{Alumni Networks Contributing to Knowledge Transfer and Their Possible Ambassador Function}

The supposed third mission of European universities (Sá, 2010; Wolfe, 2005; Benneworth \& Hospers, 2007) implies a transformation. The universities once regarded as knowledge generator expanded their role to knowledge (service) providers. In that process a strong cooperation with regions in form of their economies, policy makers and further regional authorities was demanded. In this way, alumni are welcoming instruments, supplying to the new mission of universities. Doing so, they can also contribute to regional development. Alumni who remain in the regional labour market may act as a conjunction between universities, companies and public institutions. Inducted alliances between the economy and research can promote knowledge spill over from universities to the region. This again may raise the regional knowledge base. Successful alumni affairs can provide universities with an enhanced reputation and image, which is a positive effect when regarding the universities' competitiveness. Furthermore, if alumni inhabit influential positions in businesses or public organisations, maintaining strategic contact can result in good representatives for universities. Overtaking guest lecture, agency for internships or research projects, alumni deliver students with insights into working life. This can even possibly lead to the opening of new doors for students and graduates. Alumni, who after their graduation still are in touch with their alma mater and share a positive feeling based on positive experiences made in the region during their stay can develop into advantages for the university itself and the region.

Especially in case of first living the region for a while, they can overtake an ambassador function for the university as well as the region. What is the ambassador function of alumni? Leaving the region, after a successful time of study, alumni can recommend their alma mater and the region of study to people and foremost potential students. Being themselves "successful" in life and career can be used as a marketing instrument and argument for potential student to follow the way and enrol to the same university in the same region, as their forerunner once did. Financial resources that can be generated through alumni donations or contributions must also be considered. But, the success of possible alumni contribution always depends on the input level made by individual members within their relationship with their alma mater.

\subsubsection{Return Migration Function}

As discussed above alumni networks can contribute to return migration alumni that have lived in a specific region might have a "warm place" feeling about the region they graduated in and therefore might be more eager to return. Conditions is that these alumni through the alumni network communication channels are informed about the developments and opportunities in the region

\subsection{Condition for Alumni Networks to Contribute to Retention and (Re)-Attraction}

The answer to our first question, what is the relation between brain flows and alumni, leads us to our second question. Under what conditions can alumni networks contribute to the retention and (re)-attraction of alumni in a particular region? From the discussion above for alumni networks to contribute to retention and (re)-attraction activities, three conditions have to be considered:

1) They need to be a social network

2) Thy need to have the intention to use the alumni communication channels for the region

3) They need to actively pursue through activities in the network the retention or (re)-attraction of alumni

Ad 1 If an alumni network only offers services to its members and does not stimulate the emotionally binding it will only limitedly be able to contribute to retention and (re)-attraction.

Ad 2 If an alumni network serves the sole purpose of keeping contact between student and alma mater and abstracts completely from the university region, than there is no basis to contribute to retention and (re)-attraction.

Ad 3 Through activities within the network the choice of alumni network members to stay or return can be 
influenced. Here we can learn from migration networks, which like alumni networks are social networks. Migration networks can be described as personal networks, mainly consisting of family members or closely related persons originating from the same domestic region (Pries, 2001b). Migration networks influence the decision of migrants because they function as door openers for the arrival region, helping migrants to enter to local society and labour markets. Moreover, migration networks are known as transnational (Schmiz, 2011) exchange platforms of economic, symbolic, social and cultural capital (Bourdieu, 1983). Due to new communication technology and faster mobility between regions, migration networks seem to becoming stronger as the out-migrated and migration networks exchange becomes more constant thereby enabling transnational living spaces to occur and develop freely. So communication about opportunities, welcoming culture and "what to be found" in the migration region is crucial for the migration patterns. Similar alumni networks can open doors to the region of origin and influence students' choice on staying in the region after graduation or later, as alumni, to choose whether to return. But this needs activities that also bring the region and it's opportunities under constant attention of the alumni.

\section{Method}

The empirical material is taken from the sub-project "BRAND-Border Regions Alumni Network Development", as part of the INTERREG IVC Mini Program "Brain Flow". It follows an embedded case design. The unit of analysis is university alumni networks in five countries, the Netherlands (NL), Germany (North Rhine Westphalia) (NRW/GE), Norway (NO), Sweden (SE) and Switzerland (CH). Given its size and its influence on higher education policy, this paper considers the German Federal State of North Rhine-Westphalia comparable to the other nation states.

In-depth case studies in the aforementioned countries were accomplished in five specific border regions such as Hedmark (NO), Värmland (SE), Münsterland and the Ruhr Area in North Rhine-Westphalia and NRW (GE), Overijssel (NL) and Basel $(\mathrm{CH})$. It was expected that the context of the in-depth case studies would be more similar than taking random alumni networks from the whole of these countries. The first research step was to look into the context of the border regions, to consider regional migration patterns and find possible motives for the demand and outflow of highly-skilled workers. In addition, the project looked into overall regional facts such as numbers of inhabitants and the size and infrastructure of regions. It also characterized regional education systems including regional universities and their interplay with regional economy. The goal of the 13 in-depth case studies was, against the background of their regional context, to explore the function, form and activities of alumni networks. To obtain a broader overview of the alumni networks' scope of activities, the analysis has chosen different networks according to their affiliation, life cycles and organizational and regional origin.

Table 1. In-depth case studies categorized according to their organizational and regional origin

\begin{tabular}{llllll}
\hline & $\begin{array}{l}\text { University } \\
\text { Network }\end{array}$ & $\begin{array}{l}\text { Alumni } \\
\text { Applied Sciences } \\
\text { Alumni Network }\end{array}$ & $\begin{array}{l}\text { University Faculty } \\
\text { Alumni Network }\end{array}$ & $\begin{array}{l}\text { Umbrella Alumni } \\
\text { Network }\end{array}$ & \\
\hline $\begin{array}{l}\text { North Rhine- } \\
\text { Westphalia Germany }\end{array}$ & $\mathrm{XXX}$ & $\mathrm{X}$ & $\mathrm{X}$ & \\
$\begin{array}{l}\text { Overijssel } \\
\text { Netherlands }\end{array}$ & $\mathrm{X}$ & $\mathrm{XX}$ & $\mathrm{X}$ & \\
$\begin{array}{l}\text { Värmland Sweden } \\
\text { Region Basiliens }\end{array}$ & $\mathrm{X}$ & $\mathrm{X}$ & & & $\mathrm{X}$ \\
$\begin{array}{l}\text { Swiss } \\
\text { Hedmark Norway }\end{array}$ & & $\mathrm{X}$ & & \\
\hline
\end{tabular}

A standardized questionnaire addressed to alumni network managers were used for face-to-face interviews in the in-depth case studies and desk research on these networks was accomplished. To gain further insight into what alumni networks do and how they are organized, a complementary web survey was added to the eleven alumni network case studies of the five border regions. The web survey focused on the same countries: The Netherlands, Norway, Sweden, Switzerland and the German Federal State of North Rhine Westphalia, but the web survey sample was taken from universities in all regions in these countries not just the border regions. The web survey 
limited itself to universities rather than on applied science universities. The reason for this purposeful sampling was that status, size, scope and position of applied science universities varies considerably among the countries surveyed causing comparison difficulties. The sample for the web survey consisted of 47 university alumni networks, 14 from the Netherlands, 8 from NRW (Germany), 8 from Norway, 8 from Sweden and 9 from Switzerland. It also looked into 38 faculty networks, 14 from the Netherlands, 14 from NRW (Germany), 3 from Sweden and 7 from Switzerland. Because of the diversity and unbalanced country sample the main focus of the web survey was put on the overall university network; faculty networks analysis was then used for comparison. The web survey provided less in-depth information on the scope and structure of the networks compared with the case studies, which were based on face-to-face interviews and extended document analysis even though the focus had been put on the same questions and issues. The variables and analytic elements used for the web survey were taken from the explorative in-depth case studies.

\subsection{Present Form and Function of the Networks}

The empirical analysis of the network serves to answer the third question in this paper; what is the present form and function of the studied alumni networks, is answered with the network description from the case studies and the web survey. In the in-depth case studies, analysis was made with the help of interviews and documents, analysis characteristics such as year of founding, their initiators, number of members enrolled and their structure. Further questions with regard to alumni network membership structure, finances in terms of funding, fundraising, sponsoring or members' fees, as well as organizational structure including full-time equivalences, were asked in order to assess the level of professionalization of networks. The alumni network managers were also asked about the networks' scope of activities and whom the activities were targeted at. Given this papers interest in the role of alumni networks in retention and (re)-attraction instruments, the questions asked were focused particularly on the networks' information and communication activities with regard to their individual regions. A further question was whether networks informed alumni (including those abroad) about regional news, events, economy structure, companies and job offers and if the networks already had binding instruments and activities. The case study and the web survey provided complementary information. Whereas it is difficult to generalize the description of the in-depth case studies to a larger population, the web survey information lacks detail. Based on the results of the in-depth case studies, the web survey was used to look at three groups of alumni networks characteristics:

- Organizational structure

- Network activities

- Network goals

The in-depth-case studies were used to select characteristics and to operationalize categories for the web survey. For organizational structure it looked at the same characteristics of the network as used in the in-depth case studies such as number of members enrolled, alumni network membership structure, finances in terms of funding, fundraising, sponsoring or members' fees, as well as organizational structure. Detailed information on characteristics such as initiators or full-time equivalences of the alumni organizations were difficult to obtain in the web survey.

The survey regarded the available information on networks' scopes of activities for descriptions of the activities and at whom the activities were targeted. The general activities for the web survey were designated six categories based on the overview of activities in the in-depth case studies; namely, running a webpage, offering social network or exchange possibilities, offering forms of education or courses to alumni, distributing newsletters and special magazines and an overflow category for other activities. For the overview of the goals of the network for the alumni networks, the analysis looked into the formulation of the mission, goals and tasks of the networks as published on their websites. On the basis of the in-depth case studies the goals concerning the (1) promotion of the university for future students, (2) finding future staff for the university, (3) maintaining contact and fundraising and (4) promotion of the region were considered as separate goals.

\section{Results}

\subsection{Organizational Structure}

The in-depth case studies show a low level of alumni network professionalization. With regard to management capacity, the number of employees and the full-time equivalence within the analysed networks was in generally low. Alumni networks are often led and controlled by one part-time manager although the umbrella organization CH.AN, which includes all Swiss universities of applied science, has 17 employees, of whom 10 work full-time. Only a few alumni have an official board. Staff numbers depend on funding and size of the network. The eleven case studies showed that only three networks use a fee model and that member fees represent a relatively small 
proportion of an alumni network's funds.

On the basis of the web survey, an attempt was made to trace whether fees financed networks or whether there was basic funding from the university. The type of funding is important for ways of looking at a network and also looking at the way universities can use networks. In line with the case studies in the "overall university network" sample, funding came from universities in two thirds of the networks. It is difficult from the web survey to trace the exact types of funding within the universities and there seem to be several mixed forms, but clearly, university funding dominates (more than half) followed by membership fees (about a third). This concurs with the basic university funding of the networks. Basic university funding has consequences for membership. In some cases, all graduates become members automatically or all graduates are expected to become members. As far as it could be found, network numbers varied greatly; the smallest network comprising of 1300 members and the largest of 95000. This of course depends on the size of the university and how long the university and the network have been in existence. The inventory of the faculty or education program networks indicates that they may be significantly less formally structured and financed as well as being likely to be part of the overall university alumni network. In nearly all of the studies, in networks where detailed information on organizational structure was found, there was a subdivision in alumni groups or chapters, faculty and education networks.

In relation to university funding, a wide variety of organizational units were found which were responsible for alumni policies and contacts:

- Alumni offices and bureaus;

- General university communication, marketing and external relation offices;

- Student and career services;

- General university and faculty administration units

\subsection{Network Activities}

\subsubsection{General Activities}

The case studies showed a significant similarity among the activities of the networks even when there was a notable difference in size and intensity of the activities. Based on the in-depth case studies, the network activities in the web survey were divided into six categories. The overview (Fig. 1) of the "overall alumni networks" confirms that the general activities of the analysed alumni networks are very similar. Nearly all networks have a webpage and a large majority offers a newsletter, has possibilities for social networking or exchange platforms and provides some form of education or courses for the alumni or a members' magazine. The same similarities exist between faculty networks.

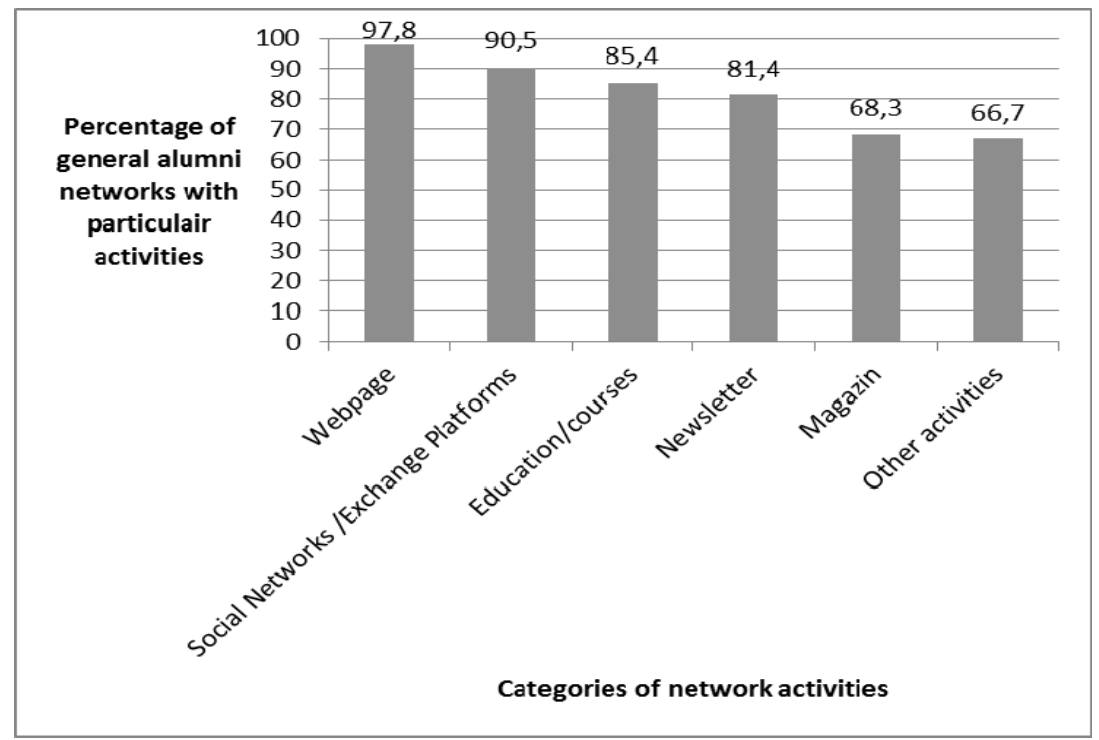

Figure 1. Percentage of the general alumni networks that perform a certain activity (column chart)

Note. Sample size: 47 general alumni networks

Source: 2012 BRAND website survey 
Questions about the networks' information and communication activities were focused with regard to the regions. One of the questions asked was whether networks inform alumni (including those living abroad) about regional news, events, economy structure, companies and their job offers.

\subsubsection{Retention Activities}

In this research study the specific interest lied in the activities of alumni networks in relation to retention and (re)-attraction. Not all retention or (re)-attraction activities carried out by alumni networks are carried out with the prime purpose of retention or (re)-attraction. Even so, they may still fulfil the possibility of graduates staying, or to consider staying, in the study region or for alumni to return, or to consider returning, to the study region. Alumni networks do have an influence on retention even if it is not intentional. Fig. 2 shows that many alumni networks organize activities, which, although not intended as retention strategies, can be used as retention activities especially when the activities show the students or graduates career possibilities in the university region. From the web survey it is difficult to determine if activities such as career or information days or field trips for students concern only career opportunities in the university home region and/or also bring students in contact with career possibilities outside the university region. However, organizing these activities offers up opportunities for improved graduate-university region linking.

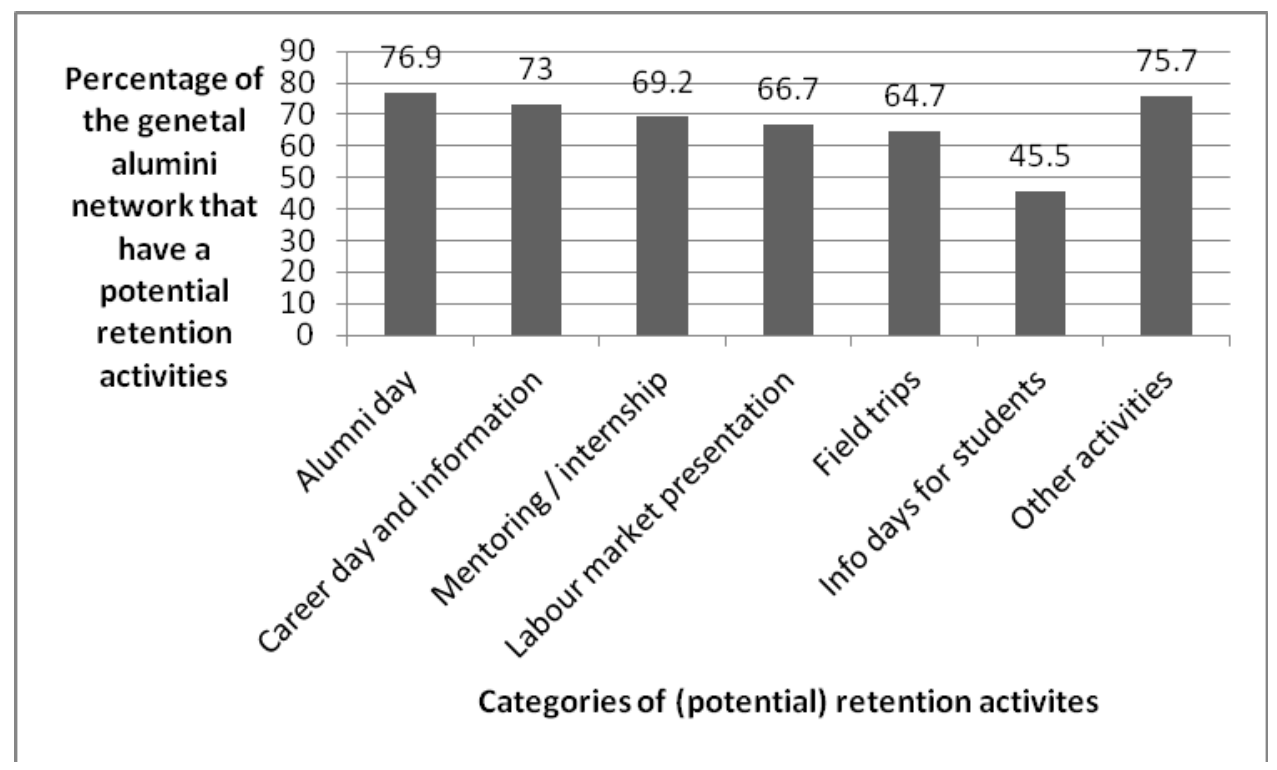

Figure 2. Percentage of the general alumni network that perform certain retention related activities (column chart)

Note. Sample size: 47 general alumni networks

Source: 2012 BRAND website survey

\subsection{3 (Re)-Attraction Activities}

What holds for retention activities is also true for (re)-attraction activities. Not all alumni networks (re)-attraction activities are intentional but they increase the likelihood of alumni returning, or of considering a return, to the study region. Alumni networks do have an influence on (re)-attraction even if it is not their primary purpose.

Fig. 3 shows that although many activities organized by alumni networks were not originally intended as (re)-attraction activities, they could in fact be used as such.

Affording a "warm place" feeling is much more important in (re)-attraction activities than in activities designed to foster retention. In the case of retention, it might just be a job offer at the university, which convinces a graduate to stay in the region. With (re)-attraction the "warm feeling" of the alumni for the particular study region is also addressed. Job offers are also a very effective pull factor for alumni. Keeping in touch through homecoming events, summer schools and student teacher exchanges can also cultivate the feeling of a possible future return but are not such concrete pull factors. However, they can be used to form a basis that concrete (re)-attraction activities can be built on. 


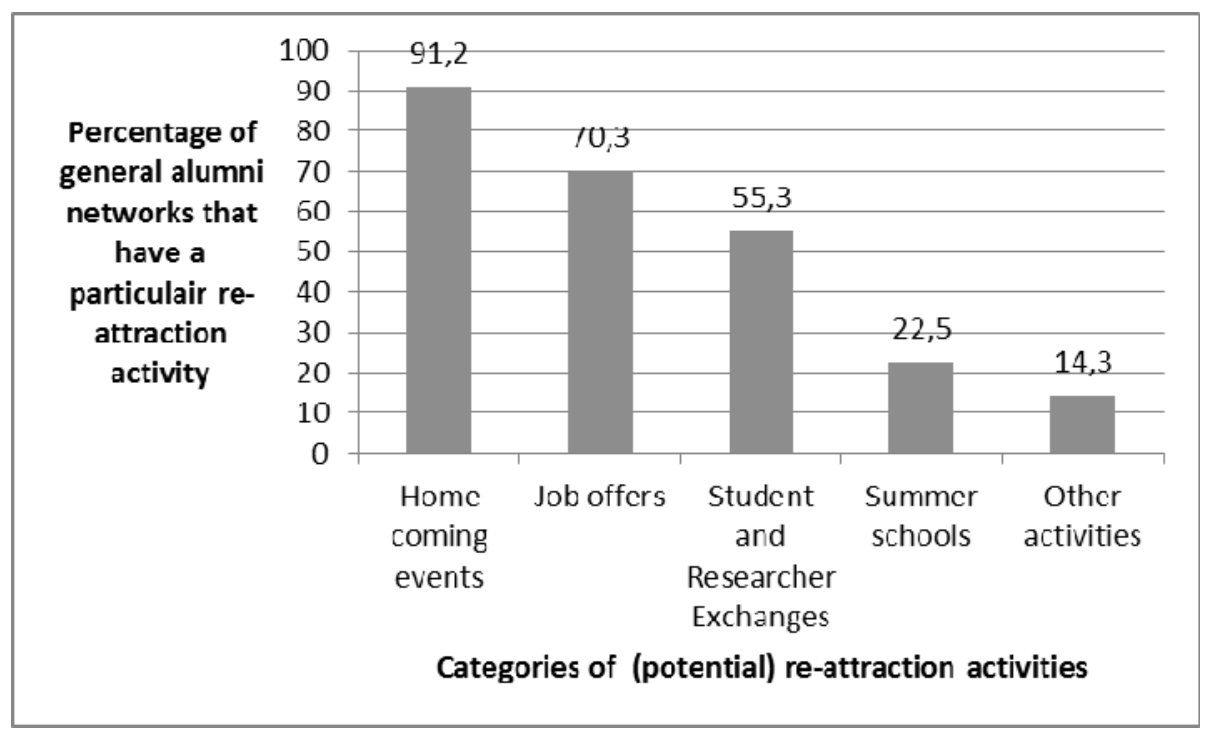

Figure 3. Percentage of the general alumni network that perform certain re-attraction related activities (column chart)

Note. Sample size: 47 general alumni networks

Source: 2012 BRAND website survey.

\subsection{Goals}

As stated above, it is possible for alumni networks to contribute to the retention of graduates and to (re)-attraction activities, even if these were not primary intentions. To discover to what extent retention and (re)-attraction activities were intentionally organized the web survey analysed mission statements and alumni network goals and tasks as formulated in the (web page) published information. In Fig. 4 the goals of the alumni networks were classified into four categories. From the survey it is clear that the networks have much broader goals than just keeping in touch with their alumni; they also require their contacts to serve a purpose. The acquisition of new students by alumni is an important goal. Alumni are potentially important promoters or ambassadors for universities and university home regions. Every contact made has the potential to lead resources to the universities. In the western European universities context, direct funding is less an issue than in the Anglo Saxon universities, although making contacts with industry could result in direct funding. Potentially recruiting university staff from alumni seems to be an important motivation for keeping alumni networks.

Maintaining contact can also mean promotion of the region by providing information on regional activities. The regional function means that through the networks' regional information and communication activities, alumni (including those abroad) are informed about regional news, events, economy structure, companies and job offers. 


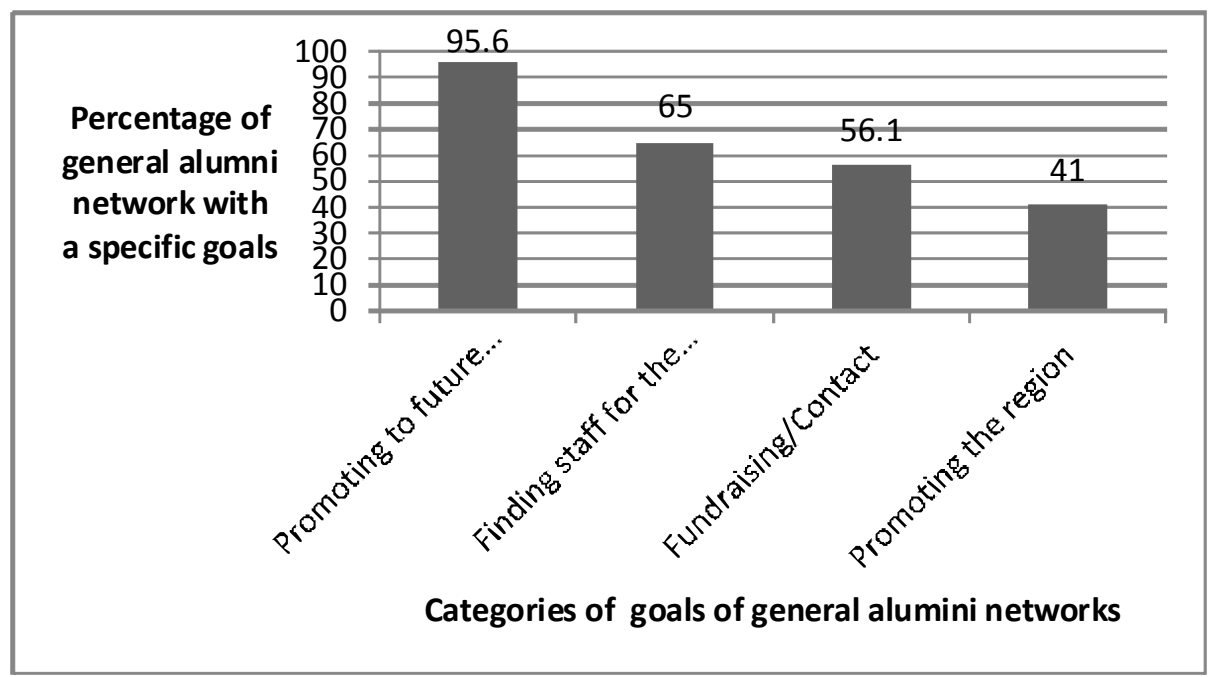

Figure 4. Percentage of the alumni networks that have the following goals

Note. Sample size: 47 general alumni networks

Source: 2012 BRAND website survey.

The specific goal of gaining resources for the universities region was also examined. If alumni networks initiated exchanges, homecoming events or internships, they were seen to be bringing in knowledge from outside the region and it was said that they were contributing to a knowledge spill over effect. Remaining in close contact with graduates and alumni contributes to human capital and workforce in the university region and is seen by many alumni networks as a task. Remaining in contact can also mean promoting the region and providing information at regional activities.

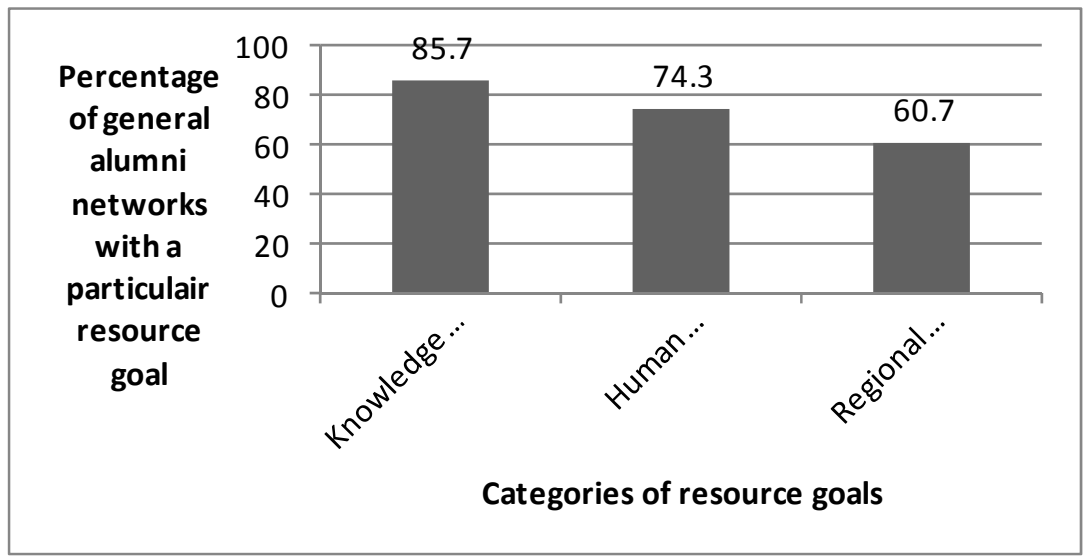

Figure 5. Percentage of the alumni networks that have the following regional resource goals

Note. Sample size: 47 general alumni networks

Source: 2012 BRAND website survey.

Although the number of the sample divided over the five countries is too small, a closer look was taken at the elements of alumni network goals and these were compared between the different countries. Although the sample is too small, Figure 6 indicates that finding new students and staff is important for all universities, but there are differences in the importance of fundraising and region promotion. Fig. 7 shows that in terms of gaining resources for the region, the resource of human capital and knowledge spill over is found in all network goals but there is a big difference in the contribution to regional attractive in the written goals. 


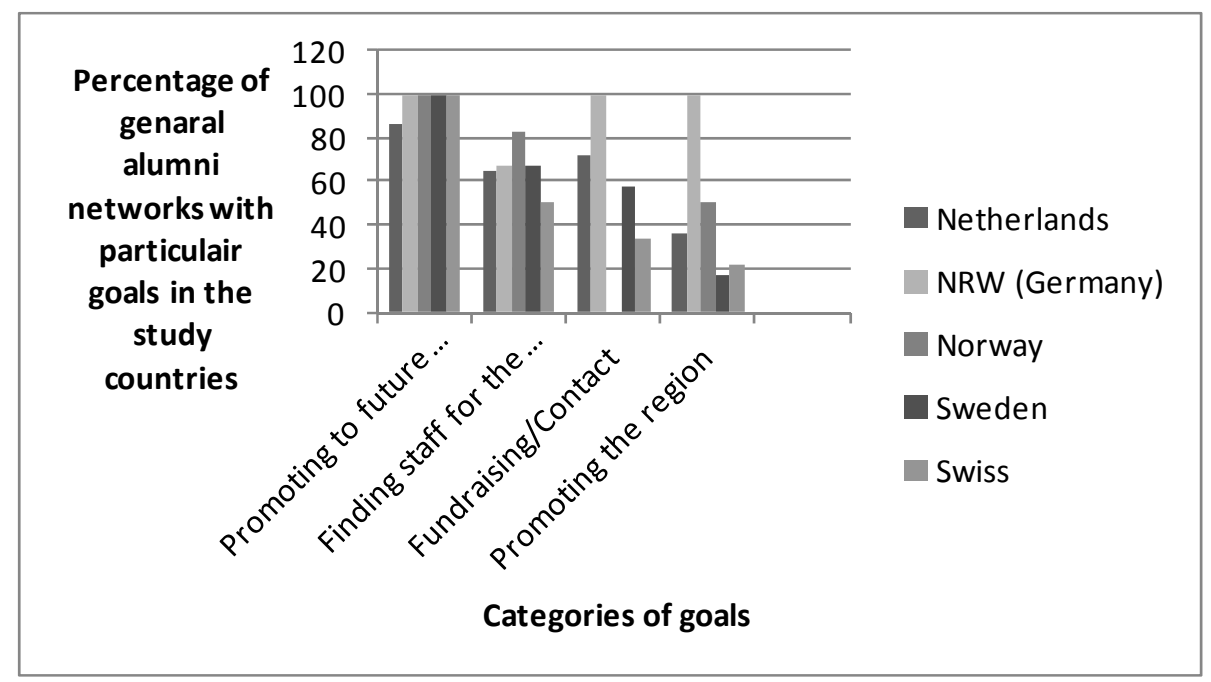

Figure 6. Percentage of the alumni networks that have the following goals compared between the countries Note. Sample size: 47 general alumni networks

Source: 2012 BRAND website survey.

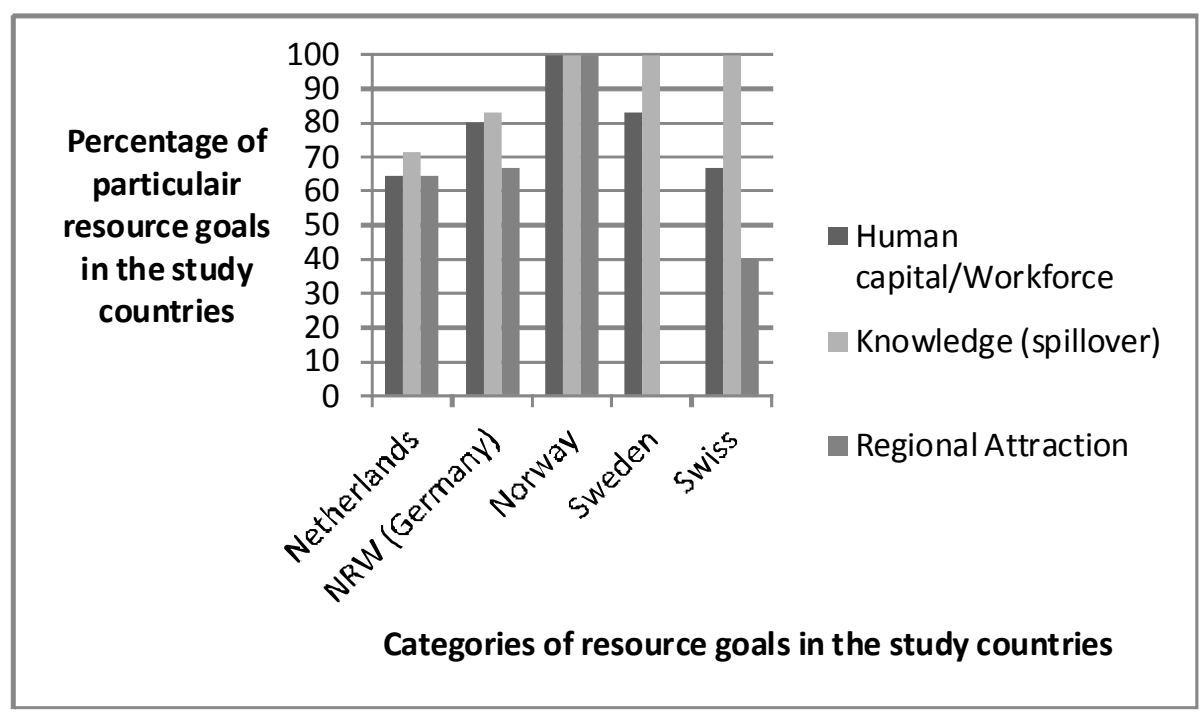

Figure 7. Percentage of the alumni networks that have the following goals concerning regional resources compared between the countries

Note. Sample size: 47 general alumni networks

Source: 2012 BRAND website survey.

\section{Conclusion}

The analyses of the present form and function of studied alumni networks brings us to the question; do the studied alumni networks fulfil the formulated conditions?

The answer to our first question, what is the relation between brain flows and alumni, shows that there is a close relation between brain flows and alumni. We argued that alumni are more open to (re)-migration to their domestic regions or the regions of their study because of the "warm feeling" they might have about and the personal networks they share with the region. Especially non-core regions might benefit from such a bond. The second question asked for the conditions under which of alumni networks could contribute to the retention and 
(re)-attraction of alumni in a particular region. We suggest, that the first condition for an alumni network to contribute is to be a social network. Fulfilling the social network function implies that the network supports the social network exchange instead selling alumni services and even more important creates an exchanging, lively groups dynamic within the network. This groups exchange in the network should not be limited to a centralized exchange between the alumni network managers and the members, but should open the possibilities and platforms for the members to also exchange among each other. A further condition is that the alumni networks use their communication channels not only for university purposes, but also use them for the purpose of the region. And as a third condition the regional function means for the alumni network activities that these should focus e.g. on communication with alumni on regional job opportunities and on a welcoming culture for graduates who stay and alumni that (re)-migrate. This needs specific network activities that bring the region and it's opportunities under constant attention of alumni.

On the basis of the in-depth case studies and the sample of the web-based analysed alumni networks in the studied countries and regions, we can conclude the following on the three-formulated conditions.

Condition one; are the analysed alumni networks social networks?

As mentioned above the pre-condition is that alumni networks are social networks based on social engagement that preserves the "warm feeling" that alumni have about their home or study region. A network build purely on providing services for the alumni would not fulfil such a social function. It is hard to judge from the web-based survey whether alumni networks really contribute to social engagement and maintain a "warm place" feeling. The in-depth case studies show that there are many different levels of personal engagement of alumni members in the network. The management and organizing capacity within the alumni networks, such as the number of employees and their full-time equivalence, is often low within the studied networks and the analysed alumni networks are often led by one part-time manager. This might also mean that there is limited time for the alumni network manager to coordinate and moderate the alumni network as a social network, although this gives no real indication that the members' exchange is high or low and if the social network function is strong or weak.

Condition two; do the analysed alumni networks have the intention to use the alumni communication channels for the region?

The accomplished research shows that the alumni network goals of promoting the region or contributing to the development of the region comes in second place after the goals for the university itself. Regarding the results of the web-based survey as well as the in-depth case studies, there are just a few alumni networks, which co-operate with the region or regional partners. Mainly these networks are umbrella organisations or specific faculty alumni networks, which try to bind their best graduates to the regional labour market or to the university itself.

Condition three; do the analysed alumni networks actively pursue through activities in the network the retention or (re)-attraction of alumni?

The research shows that in so far there are activities of studied alumni networks in relation to retention and (re)-attraction, such as carrier information events, summer schools, home coming events and regional focus groups, many of the named activities are not carried out with the prime purpose of retention or (re)-attraction, but can be regarded as unintentional side effects.

The present analysed alumni networks fulfil the conditions to support retention and (re)-attraction activities only partially. As lined out, our examples show that the alumni activities are mainly social networks exchange activities. The survey did find some examples of alumni networks, which use their communication channels and communication platform for activities that go beyond the social network function and the communication about the university activities, for instance regional job-related issues and information on developments in the region. Considering retention and (re)-attraction activities, there are some examples of alumni networks, which run relevant activities. But although the potential effects of these activities on retention and (re)-attraction are unintentional and not the main goal of these activities nonetheless it means for the studied regions that there is an untapped potential of the present alumni networks to play a larger role in the retention and (re)-attraction of highly-skilled alumni. But looking at the present conditions in the studied alumni networks, they should be more professionalized in the sense of organizational structure (number of employees, board, and full-time equivalence). Furthermore, it would need closer co-operation within the university and a collaboration of alumni networks with the university career centres, press offices and career counselling. In addition, the alumni networks themselves, if they take their potential retention and (re)-migration function serious, should open up to other regional stakeholders such as companies, chambers of commerce etc. And the alumni network activities should than take up retention and re-attraction as intentional effects of their activities. 


\section{Acknowledgments}

The outcomes and results used for this paper base on a survey accomplished under the sub-project "BRAND-Border Regions Alumni Network Development" as part of the INTERREG IVC Mini Program "Brain Flow".

\section{References}

Andrews, R. (2012). Labour migration, communities and perceptions of social cohesion in England. European Urban and Regional Studies, 0(0), 1-15.

Appadurai, A. (2008). Modernity at large. Cultural mimenstions of globalization. Minneapolis, London: University of Minnesota Press.

Bathel, H., Malmberg, A., \& Maskell, P. (2004). Clusters and knowledge: local buzz, global pipelines and the process of knowledge creation. Progress in Human Geography, 28, 31-56. http://dx.doi.org/10.1191/0309132504ph469oa

Bhabha, H. (2000). Die Verortung der Kultur. Tübingen: Stauffenburg Verlag.

Benneworth, P., \& Hospers, G-J. (2007). The new economic geography of old industrial regions: Universities as global/local pipelines. Environmental and Planning C: Government and Policy, 25(6), 779-802. http://dx.doi.org/10.1068/c0620

Boshuizen, J. (2009). Join the Club! Knowledge spillovers and the influence of social networks on firm performance. Dissertation, University of Twente.

Bourdieu, P. (1983). Ökonomisches Kapital, kulturelles Kapital, soziales Kapital. In R. Kreckel (Ed.), Soziale Ungleichheiten, Soziale Welt Sonderband 2 (pp. 183-198). Göttingen.

Bressers, H., Th, A., \& O’Toole, L. J. (1998). The selection of policy instruments: A network-based perspective. Cambridge University Press, 18(3), 213-239.

Butzin, B. (2000). Netzwerke, Kreative Milieus und Lernende Regionen: Perspektiven für die regionale Entwicklungsplanung? Zeitschrift für Wirtschaftsgeographie Jg. 44 Heft 3/4, 149-166.

Cassarino, J. P. (2004). Theorising return migration: The conceptual approach to return migrants revisited. International Journal on Multicultural Societies IJMS, 6(2), 253-279.

Castells, M. (2008). The new public sphere: Global civil society, communication networks, and global governance. The ANNALS of the American Academy of Political and Social Science, 616, 78-93. http://dx.doi.org/10.1177/0002716207311877

Champion, T. (2011). Testing the return migration element on the 'escalator region' model: an analysis of migration into and out of South-East England, 1966-2001. Cambridge Journal of Regions, Economy and Society, 1-15.

Coenen, F., \& Fikkers, D. J. (2010). Human capital in European peripheral regions: brain drain and brain gain. In H. Pechlaner, \& M. Bachinger (Eds.), Lebensqualität als Standtortfaktor. Kultur, Mobilität und regionale Marken als Erfolgsfaktoren (pp. 117-132), Berlin: Erich Schmidt Verlag GmbH.

Coleman, J. S. (1988). Social capital in the creation of human capital. The American Journal of Sociology, Supplement: Organizations and Institutions: Sociological and Economic Approaches to the Analysis of Social Structure, 94, 95-120.

Cook, P. (2001). Regional innovation systems, clusters, and the knowledge economy. Industrial and Corporate Change, 10(4), 945-974. http://dx.doi.org/10.1093/icc/10.4.945

David, A., \& Hamburg, I. (2013). Integrating vulnerable and marginalized groups into vocational education and training through innovative solutions. Problems of Education in the 21st Century, 56, 42-58.

David, A., Barwinska-Malajowicz, A., \& Coenen, F. (2012). From brain drain to brain exchange: How to use better highly skilled workers; a conceptual approach. Unia Europejska.pl, 216(5), 25-35.

Etzkowitz, H., \& Leydesdorff, L. (2000). The dynamics of innovation: From national system and "mode 2" to a Triple Helix of university-industry-government relations. Research Policy, 9(2), 109-123. http://dx.doi.org/10.1016/S0048-7333(99)00055-4

Faggian, A., \& McCann, P. (2008). Human capital, graduate migration and innovation in British regions. Cambridge Journal of Economics, 33, 317-333. http://dx.doi.org/10.1093/cje/ben042 
Florida, R. (2008). Who's your city? How creative economy is making where to live the most important decision of your life. New York: Basic Books.

Fürst, D., \& Schubert, H. (1998). Regionale Akteursnetzwerke. Zur Rolle von Netzwerken in regionalen Umstrukturierungsprozessen. Raumforschung und Raumordnung (RuR), 352-361. http://dx.doi.org/10.1007/BF03183758

Gibbons, M. (1994). The New Production of Knowledge: The Dynamics of Science and Research. Contemporary Societies. London: Sage.

Granovetter, M. S. (1973). The strength of weak ties. The American Journal of Sociology, 78(6), 1360-1380. http://dx.doi.org/10.1086/225469

Growe, A. (2009). Knowledge-holders and networking in metropolitan regions. Spatial requirements of knowledge-holders and the combination of politics. Raumforschung und Raumordnung, 5/6, 383-394. http://dx.doi.org/10.1007/BF03185713

Henning-Thurau, T., Langer, M. F., \& Hansen, U. (2001). Modeling and managing student loyalty. Journal of Service Research, 3(4), 331-344. http://dx.doi.org/10.1177/109467050134006

Heßler, M. (2008). Science cities, creativity, and urban economic effects. In M. Heßler, \& C. Zimmermann (Eds.), Creative Urban Milieus (pp. 311-334). Frankfurt am Main, Campus Verlag GmbH.

Hospers, G. J. (2010). Making sense of place: From cold to warm city marketing. Journal of Place Management and Development, 3(3), 182-193. http://dx.doi.org/10.1108/17538331011083925

King, R. (1978). Return migration: A neglected aspect of population geography. The Royal Geographical Society Area, 10(3), 175-182 (with the Institute of British Geographers).

Klagge, B., \& Klein-Hitpaß, K. (2010). High-skilled return migration and knowledge-based development in Poland. European Planning Studies, 18(10), 1632-1651. http://dx.doi.org/10.1080/09654313.2010.504346

Kroll, H., Schricke, E., \& Stahlecker, T. (2013). Scope and determinants of the 'third role' of higher education institutions in Germany. Higher Education Policy, 26, 263-284. http://dx.doi.org/10.1057/hep.2013.1

Lowe, M. S., Williams, A. M., Shaw, G., \& Cudworth, K. (2012). Self-organizing innovation networks, mobile knowledge carriers and diasporas: Insights from a pioneering boutique hotel chain. Journal of Economic Geography, 12, 1113-1138. http://dx.doi.org/10.1093/jeg/lbs021

Malecki, E. J. (2011). Regional social capital: Why it matters? Regional Studies, 46(8), 1023-1039. http://dx.doi.org/10.1080/00343404.2011.607806

Malmberg, A., \& Power, D. (2005). (How) do (firms in) clusters create knowledge? Industry and Innovation, 12(4), 409-431. http://dx.doi.org/10.1080/13662710500381583

Martin, R., \& Sunley, P. (2006). Path dependence and regional economic evolution. Journal of Economic Geography, 6(4), 395-437. http://dx.doi.org/10.1093/jeg/lb1012

McDearmon, J. T. (2011). Hail to thee, our alma mater: Alumni role identity and the relationship to institutional support behaviors. Research of Higher Education.

Niebergall, C. (2007). Alumni-Organisationen als Netzstrukturen. Eine theoretische und empirische Untersuchung. Inaugural-Dissertation zur Erlangung des akademischen Grades eines Doktors der Wirstchaftswissenschaften am Fachbereich Wirtschaftswissenschaften der Bergischen Universität Wuppertal.

OECD, (2013). International migration outlook. Paris: OECD Publishing. http://dx.doi.org/10.1787/migr_outlook-2013-en

Porter, M. (1998). Clusters and the new economics of competition. Harvard Business Review, 77-90.

Pries, L. (2011). Transnationale Migration als Innovationspotenzial. In K. Engel, J. Großmann, \& B. Hombach (Eds.), Phönix flieg!: Das Ruhrgebiet entdeckt sich neu. Essen: Klartext.

Pries, L. (2001a). Internationale Migration. Bielefeld: transcript Verlag.

Pries, L. (2001b). New transnational social spaces. International migration and transnational companies. London: Routledge.

Rehfeld, D. (1994). Produktionscluster und räumliche Entwicklung: Beispiele und Konsequenzen. In W. Krumbein (Ed.), Ökonomische und politische Netzwerke in der Region: Beiträge aus der internationalen 
Debatte (pp. 187-205). Münster: Lit-Verl.

Rohlmann, A., \& Wömper, A. (2009). Alumni relationship management als Erfolgsfaktor im Wettbewerb der $\begin{array}{llllll}\text { Hochschulen. } & \text { Zeitschrift } & \text { für } & \text { Betreibswirtschaft } & \text { ZfB, } & 79,\end{array}$ http://dx.doi.org/10.1007/s11573-009-0230-4

Sá, C. M. (2010). Redefining university roles in regional economies: A case study of university-industry relations and academic organization in nanotechnology. Higher Education, 61, 193-208. http://dx.doi.org/10.1007/s10734-010-9332-8

Saxenian, A. (2006). The New Argonauts, regional advantage in a global economy. Cambridge, Massachusetts, London, England: Harvard University Press.

Schmitz, A. (2013). Transnational leben. Bildungserfolgreiche (Spät-)Aussiedler zwischen Deutschland und Russland. Bielefeld transcript: Verlag. http://dx.doi.org/10.14361/transcript.9783839423288

Schmiz, A. (2011). Transnationalität als Ressource? Netzwerke vietnamesischer Migrantinnen und Migranten zwischen Berlin und Vietnam. Bielefeld: transcript Verlag.

Seppänen, S. K. (2008). Regional innovation systems and regional competitiveness: An analysis of competitiveness indexes. Paper to be presented at DRUID-DIME Academy, Winter $2008 \mathrm{PhD}$ Conference on Geography, Innovation and Industrial Dynamics.

Smeulders, E., \& Latten, J. (2009). De verborgen aantrekkingskracht van Parkstad Limburg. Bevolkingstrends 2nd Quarter, 26-33.

Stark, O., \& Byra, L. (2012). A back-door brain drain. ZEF-Discussion Papers on Development Policy No. 164. Zentrum für Entwicklungsforschung. Retrieved from http://ssrn.com/abstract=2037840

Stark, O. (2005). The New Economics of the Brain Drain. World Economics, 6(2), 136-140.

Stifterverband für die deutsche Wissenschaft. (2000). Alumni Netzwerke. Strategien der Absolventenarbeit an Hochschulen. Dokumentation des Symposiums "Die Entdeckung der Alumni” vom 6./7. Dezember 2000 im Wissenschaftszentrum Bonn und des Wettbewerbs "AlumniNetzwerke".

Stockhorst, J. (2011). Verfügbarkeit von hoch qualifizierten Arbeitskräften abseits von Ballungsräumen. Regionale Restriktionen und Chancen für Hochtechnologieunternehmen der Medizintechnik. Stadt und Regionalforschung. Berlin: LIT VERLAG, Dr. W. Hopf.

Sung, M., \& Yang, S-U. (2008). Student-university relationships and reputation: A study of the links between key factors fostering students' supportive behavioral intentions towards their university. Higher Education, 57, 787-811. http://dx.doi.org/10.1007/s10734-008-9176-7

Trippl, M., \& Maier, G. (2007). Knowledge spillover agents and regional development. Working Paper of DYNREG - Dynamic Regions in a Knowledge-Driven Global Economy Lessons and Policy Implications for the EU.

Ulku, A. M., \& Ulku, H. (2011). Integration, social networks and economic success of immigrants: A case of the $\begin{array}{lllll}\text { Turkish community } & \text { in }\end{array}$ http://dx.doi.org/10.1111/j.1467-6435.2011.00510.x

Wagner, M., Fialkowska, K., Piechowska, M., \& Lukowski, L. (2013). Deutsches Waschpulver und polnische Wirtschaft. Die Lebenswelt polnischer Saisonarbeiter. Ethnographische Beobachtungen. Bielefeld: transcript Verlag.

Weerts, D. J., Cabrera, A. F., \& Sanford, T. (2010). Beyond giving: Political advocacy and volunteer behaviors of public university alumni. Research of Higher Education, 51(4), 346-365. http://dx.doi.org/10.1007/s11162-009-9158-3

Wolfe, D. A. (2005). The role of universities in regional development and cluster formation. In G. A. Alan, P. L. McCarney, \& M. L. Skolnik (Eds.), Creating Knowledge, Strengthening Nations: The Changing Role of Higher Education (pp. 167-194). University of Toronto Press. 


\section{Copyrights}

Copyright for this article is retained by the author(s), with first publication rights granted to the journal.

This is an open-access article distributed under the terms and conditions of the Creative Commons Attribution license (http://creativecommons.org/licenses/by/3.0/). 